INTERNATIONAL MONETARY FUND

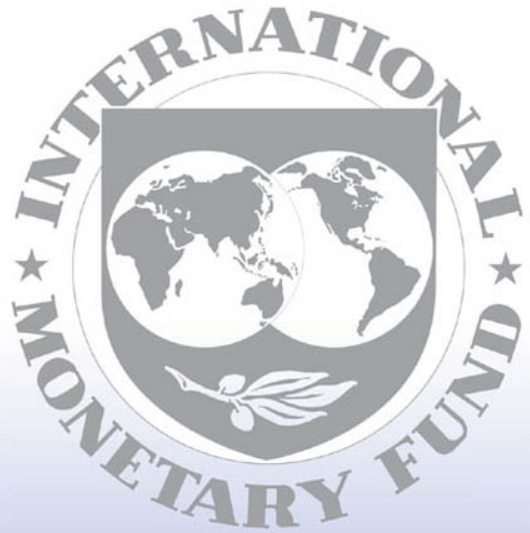

Staff

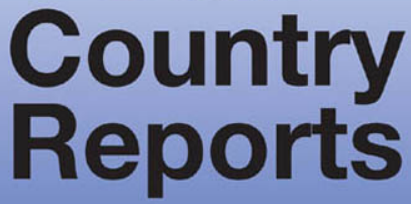




\section{Kenya: Selected Issues}

This Selected Issues paper for Kenya was prepared by a staff team of the International Monetary Fund as background documentation for the periodic consultation with the member country. It is based on the information available at the time it was completed on August 21, 2008. The views expressed in this document are those of the staff team and do not necessarily reflect the views of the government of Kenya or the Executive Board of the IMF.

The policy of publication of staff reports and other documents by the IMF allows for the deletion of market-sensitive information.

Copies of this report are available to the public from

International Monetary Fund • Publication Services

700 19th Street, N.W. • Washington, D.C. 20431

Telephone: (202) 623-7430 • Telefax: (202) 623-7201

E-mail: publications@imf.org • Internet: http://www.imf.org

Price: $\$ 18.00$ a copy

International Monetary Fund

Washington, D.C. 
This page intentionally left blank

(CInternational Monetary Fund. Not for Redistribution 


\section{INTERNATIONAL MONETARY FUND}

\section{KENYA}

\section{Selected Issues}

Prepared by Yongzheng Yang (AFR), Greetje Everaert (FAD), James John (PDR), and Olessia Korbut (AFR)

Approved by African Department

August 21, 2008

Contents

Summary and Overview $\underline{2}$

I. Assessing Kenya's External Stability and Competitiveness .4

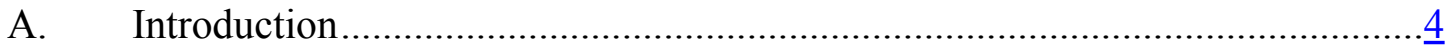

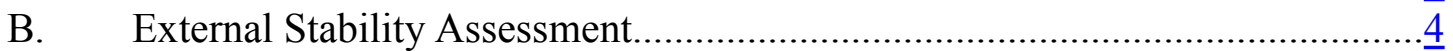

C. Competitiveness Assessment ……………….......................................

D. Concluding Remarks.............................................................................

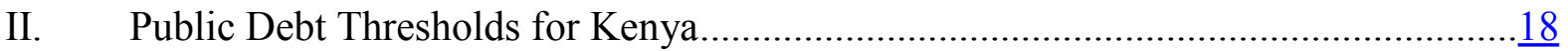

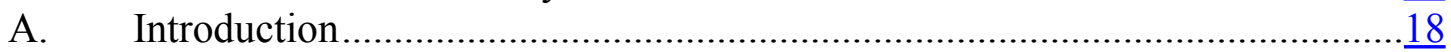

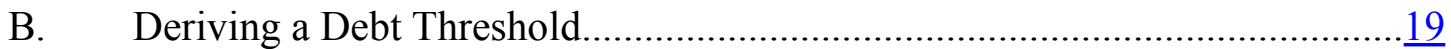

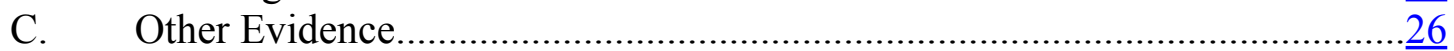

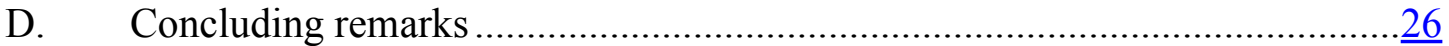




\section{SUMMARY AND OVERVIEW ${ }^{1}$}

The following two chapters provide background analysis to two central issues of the 2008 Article IV consultation with Kenya. The first chapter reviews Kenya's external stability in a context where the exchange rate has strengthened and capital inflows are playing an increasingly important role. The second chapter discusses the merits of a new anchor for medium-term fiscal policy - in a changing environment where potential access to international borrowing warrants a fresh look at the framework for fiscal policy.

Chapter I, Assessing External Stability and Competitiveness, is motivated by significant changes in Kenya's external sector in recent years as well as the Fund's emphasis on external stability in its surveillance. Kenya's current account deficit has widened considerably amid the rapid real appreciation of the shilling. Yet, exports have held up quite well, and the increasing current account deficit reflects in part higher oil prices. Moreover, increasing financial inflows have more than covered the rising import bill and allowed for a steady build-up of foreign reserves.

Against this background, the paper examines whether Kenya's real effective exchange rate is in line with economic fundamentals. It finds that the real appreciation of the shilling over the past three years has been largely driven by the rising prices of tea and coffee-Kenya's major exports - a strengthening foreign asset position, and productivity improvements. Kenya's current account deficit is also estimated to be within a sustainable level, although recent trends and forecasts point to a closing of this gap. However, the current and projected levels of the current account deficit are too high to stabilize Kenya's current net foreign liabilities, which are relatively low.

Taken together, the results do not point to major concerns about external stability at present. The findings are consistent with the results of an in-depth analysis of Kenya's export competitiveness. Recent productivity gains - as reflected in falling unit labor cost - have enabled Kenya to expand its exports to its own region and allowed some, albeit modest, recovery in Kenya's global market share. Strengthening competitiveness depends foremost on reducing nonfactor costs (e.g., energy, transport, and security).

Chapter II, Public Debt Thresholds for Kenya, considers public debt thresholds for Kenya against the background of falling domestic debt and planned access to international capital markets. In the past, domestic borrowing has served as the authorities' fiscal anchor, and this helped bring down domestic debt and provided room for private credit growth. However, with planned external borrowing, a broader concept of public debt (including domestic but also external debt) would seem a more suitable anchor for medium-term fiscal policy.

Based on cross-country analysis, the paper finds that a public debt-to-GDP ratio of about 35 percent of GDP would be broadly appropriate for Kenya-a target consistent with the

\footnotetext{
${ }^{1}$ Prepared by Yongzheng Yang.
} 
experience of emerging market economies, a group toward which Kenya hopes to move. With public debt still close to 40 percent of GDP and a considerable stock of contingent liabilities, the results suggest to aim for a gradual reduction of public debt (in relation to GDP) over the medium term - an objective consistent with the targets in the government's 2008 Budget Strategy Paper. Year-to-year fluctuations in spending around such a path should be accommodated if warranted by specific circumstances - for example, large privatization receipts should result in faster debt reduction, whereas emergencies and weak growth could entail a smaller consolidation in a given year. 


\section{Assessing Kenya's EXternal Stability and Competitiveness ${ }^{1}$}

\section{A. Introduction}

1. The Kenyan shilling has appreciated considerably over the past three years (through end-2007), both in nominal and real effective terms. Over the same period, Kenya's external current account deficit has widened, reflecting strong import volumes as well as rising import prices, particularly for oil, but external debt as a percent of GDP has declined steadily. Underlying these developments have been a steady increase in capital inflows and a remarkable rebound of economic growth since 2003 after two decades of stagnation. As a result, despite a widening current account deficit, foreign exchange reserves held by the Central Bank of Kenya have risen and reserve coverage of imports has increased. A key challenge to maintain the recent growth momentum - assuming that the recent post-election violence has only been a temporary setback - will be to ensure that the real value of the shilling is consistent with maintaining both medium-term external stability and competitiveness.

This paper assesses this consistency from three different angles. We first apply three commonly used methodologies to examine whether the shilling's real effective exchange rate (REER), Kenya's current account balance, and its net foreign asset position are in line with the country's economic fundamentals. We then evaluate the competitiveness of Kenya's export sector based on estimates of unit labor cost. Finally, we examine Kenya's export growth in recent years using a constant market share analysis.

\section{B. External Stability Assessment}

2. We begin our assessment by updating and refining an earlier study by Cheng (2004), which applies a behavioral equilibrium real exchange rate approach. Under this approach, a set of economic fundamentals that underpin REER developments is identified and regressed on the REER. The regression-predicted REER levels are then compared with actual observations. If the results indicate a higher (more appreciated) level of the actual exchange rate, this could signify a possible overvaluation.

3. The literature on determinants of real effective exchange rates is extensive, but empirical analysis differs depending on which fundamentals are appropriate for each economy and data availability. The REER is hypothesized to depend on the following five fundamental variables (see Data Appendix for further discussion of variables used in this analysis):

- $\quad$ Productivity - The Balassa-Samuelson theory suggests that faster productivity increases in the traded goods sectors relative to major trading partners would lead to

\footnotetext{
${ }^{1}$ This paper was prepared by Yongzheng Yang, Olessia Korbut, and James John.
} 
REER appreciation over time. We compared Kenya's relative productivity to: i) major competitors for coffee and tea - Colombia, Sri Lanka, Uganda, and Tanzania (see discussion below) and ii) its major trading partners. Real GDP per capita was used as a proxy for productivity.

- $\quad$ Terms of Trade - An improvement in the terms of trade appreciates the REER by raising a country's income and increasing consumption, which will be divided between traded and non-traded goods. If demand and supply for non-traded goods is in equilibrium, then an improvement in the terms of trade will increase demand for non-traded goods and may lead to REER appreciation. Coffee and tea are two main commodities that account for nearly a quarter of Kenya's total merchandise exports. Cheng (2004) finds that this variable has more power to explain REER developments than terms of trade, which was tested as an alternative to tea and coffee prices in this study.

- $\quad$ Trade Openness - A more liberal trade regime lowers domestic prices and leads to a more depreciated REER, whereas trade restrictions may appreciate the rate. However, a more liberal trade regime is also likely to improve productivity in the tradable sector, which could counter the downward pressure of trade liberalization on the real effective exchange rate. Thus the actual effect of trade restrictions depends on individual country circumstances, although empirically, most studies have found that trade openness leads to REER depreciation. As trade restrictions and controls are difficult to quantify, openness is used as a proxy here.

- $\quad$ International Investment Position (IIP) - Economies with relatively high net foreign assets (NFA) can afford a more appreciated REER, while debtor countries will need a more depreciated REER to generate trade surpluses given their external liabilities. In the absence of IIP data for Kenya, two IIP proxies are used: i) banking sector NFA and ii) a crude estimate of Kenya's IIP derived from current account data.

- $\quad$ Public Consumption - Higher public consumption is expected to appreciate the REER by increasing the demand for goods. To the extent government expenditure is more heavily weighted towards non-tradable than tradable goods, the real effective exchange rate may appreciate. Cheng (2004) finds that public consumption is not an explanatory fundamental variable for Kenya's REER.

4. In light of the recently discovered overstatement of inflation by Kenya's official CPI, we constructed a new CPI series to recalculate Kenya's REER. The new series removes the upward bias in the food

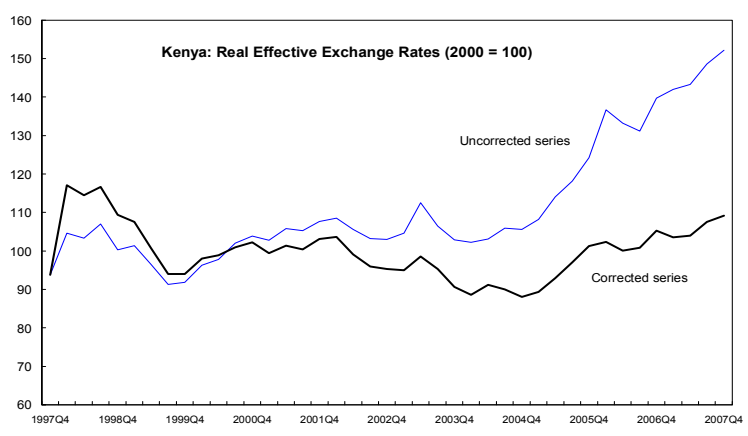


component of the official CPI after 1997. ${ }^{2}$ The results show a much slower pace of appreciation of the shilling over the past few years (Figure 1).

5. The results of the estimated equilibrium long-run relationship between the real exchange rate and the aforementioned variables which have explanatory power for Kenya's real exchange rate are presented in Table 1. All the presented coefficients have the expected signs and are statistically significant. All the models were estimated with the dynamic ordinary least square method (Stock and Watson, 1993).

6. The regression results show that the real appreciation of the shilling over the three years through end-2007 has essentially been driven by improvements in economic fundamentals. ${ }^{3}$ In fact, the Kenyan shilling appears to have been undervalued over the period 2002-04 - after three years (1998-2001) of overvaluation driven by high inflation. The 200204 undervaluation seems to reflect a slow market reaction to improved economic conditions.

Table 1. Equilibrium Real Exchange Rates: Regression Results

\begin{tabular}{lcc}
\hline Explanatory variable & Estimated coefficient & t-statistic \\
\hline Net foreign assets (percent of GDP) & 0.014 & 3.86 \\
Trade Openness (in logs, percent of GDP) & -0.275 & -3.25 \\
Real tea and coffee prices (in logs, index) & 0.192 & 7.51 \\
Productivity differential (in logs, index) & 0.300 & 2.83 \\
& & \\
Number of observations & & 110 \\
Adjusted $\mathrm{R}^{2}$ & \multicolumn{2}{c}{0.654} \\
\hline
\end{tabular}

Note: All coefficients are significant at 1 percent level.

\footnotetext{
${ }^{2 \backslash}$ Given the large weight of food in Kenya's CPI basket and the nature of the upward bias-it increases with the degree of price volatility, removing the bias in the food component of the CPI should correct for most of the overall bias.

${ }^{3}$ This finding is consistent with that of Kiptui and Kipyegon (2008), which used some different explanatory variables and a different estimation method from this paper.
} 


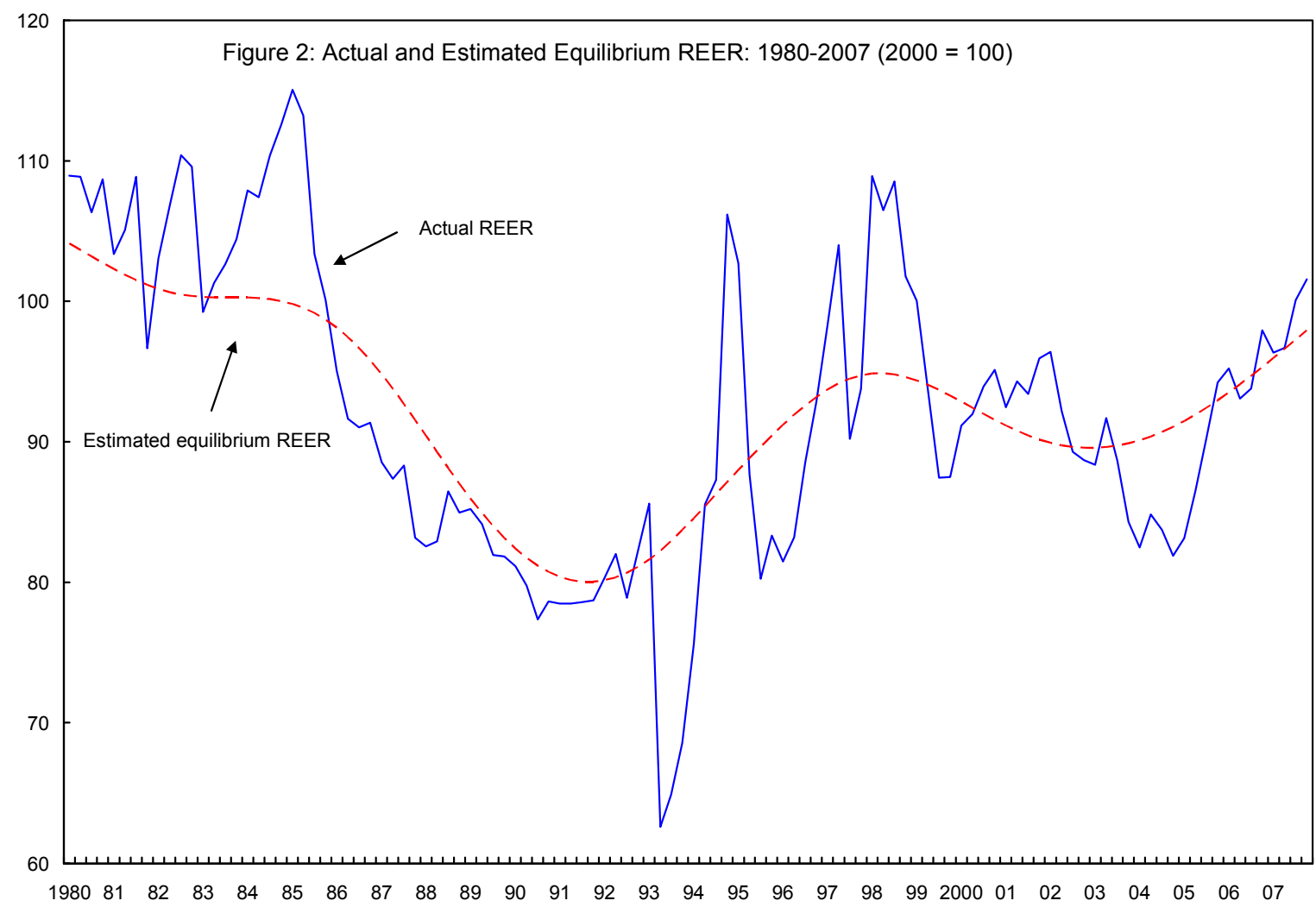

7. Decomposing the change of the equilibrium REER over the period 2005-2007 shows that the bulk of the appreciation has been driven by the upsurge of tea and coffee prices in the world market and a strengthening net foreign asset position. ${ }^{4}$ Recent improvements in productivity also contributed to the shilling's real appreciation, while changes in openness during this period had only a marginal effect on the exchange rate.

Table 2. Kenya: Contributions to REER Appreciation, 2005-07

\begin{tabular}{lr}
\hline Variable & Percent of total \\
\hline Productivity & 5.8 \\
NFA to GDP & 9.7 \\
Coffee/Tea Price Index & 81.0 \\
Openness to Trade & 1.6 \\
\hline
\end{tabular}

Source: IMF staff estimates.

8. As mentioned earlier, several other configurations of explanatory variables were tested. The crude estimate of Kenya's IIP described above was not statistically significant and did not perform as well as banking sector NFA. We found that the terms of trade (in

\footnotetext{
${ }^{4}$ To the extent that there has been a common boom in most commodities, the strong effect of rising tea and coffee prices on the shilling may have also captured the effect of Kenya's booming horticultural exports, which account for another quarter of Kenya's total exports.
} 
place of tea and coffee prices) is marginally significant (at 10 percent) but substantially reduces the goodness of fit of the regressions, and splitting the terms of trade into export and import prices did not produce significant coefficients. The oil price was also insignificant as an explanatory variable. Similarly, we found that relative productivity with Kenya's competitive partners, Colombia, Sri Lanka, Tanzania and Uganda - which are major tea and coffee producers, produced a model with a better fit than productivity relative to trading partners. Similar to Cheng (2004), public consumption did not seem to increase the overall goodness of fit of the model and was also insignificant.

9. Under the second approach we employed to assess the REER, the regression results from an IMF study (Lee et al., 2008) were used to derive the levels of the equilibrium current account balance for Kenya. This approach is similar to the first approach in that the economic fundamentals and demographic characteristics of a particular country are used to derive current account "norms"- - levels considered to be sustainable. If the current account balance is found to deviate from the norms, estimates of REER adjustments to bring the current account back to equilibrium can be calculated based on trade elasticities with respect to the REER. One important caveat to note is that the results (Lee et al., 2008) are based on advanced and emerging market data, and as a result, the regression coefficients and the current account norms derived from them may not be fully applicable to Kenya, or for that matter, to other low-income countries. ${ }^{5}$ Indeed, it seems plausible that Kenya's current account norm could be lower (i.e., larger current account deficits) than even emerging market economies as the country receives foreign aid on a continuous, albeit modest, basis.

10. Our calculations show that Kenya's current account deficit has been generally smaller than its estimated norms except for a short period during the second half of the 1990s (Figure 3). However, it is important to note that the margin has been narrowing rapidly since 2002, when Kenya ran a current account surplus of 2 percent of GDP. With the current account deficit forecast to widen further over the medium term and perhaps breach the norms in 2008, future developments need to be monitored closely.

\footnotetext{
${ }^{5}$ The IMF's Research Department is in the process of estimating such coefficients for low-income countries.
} 


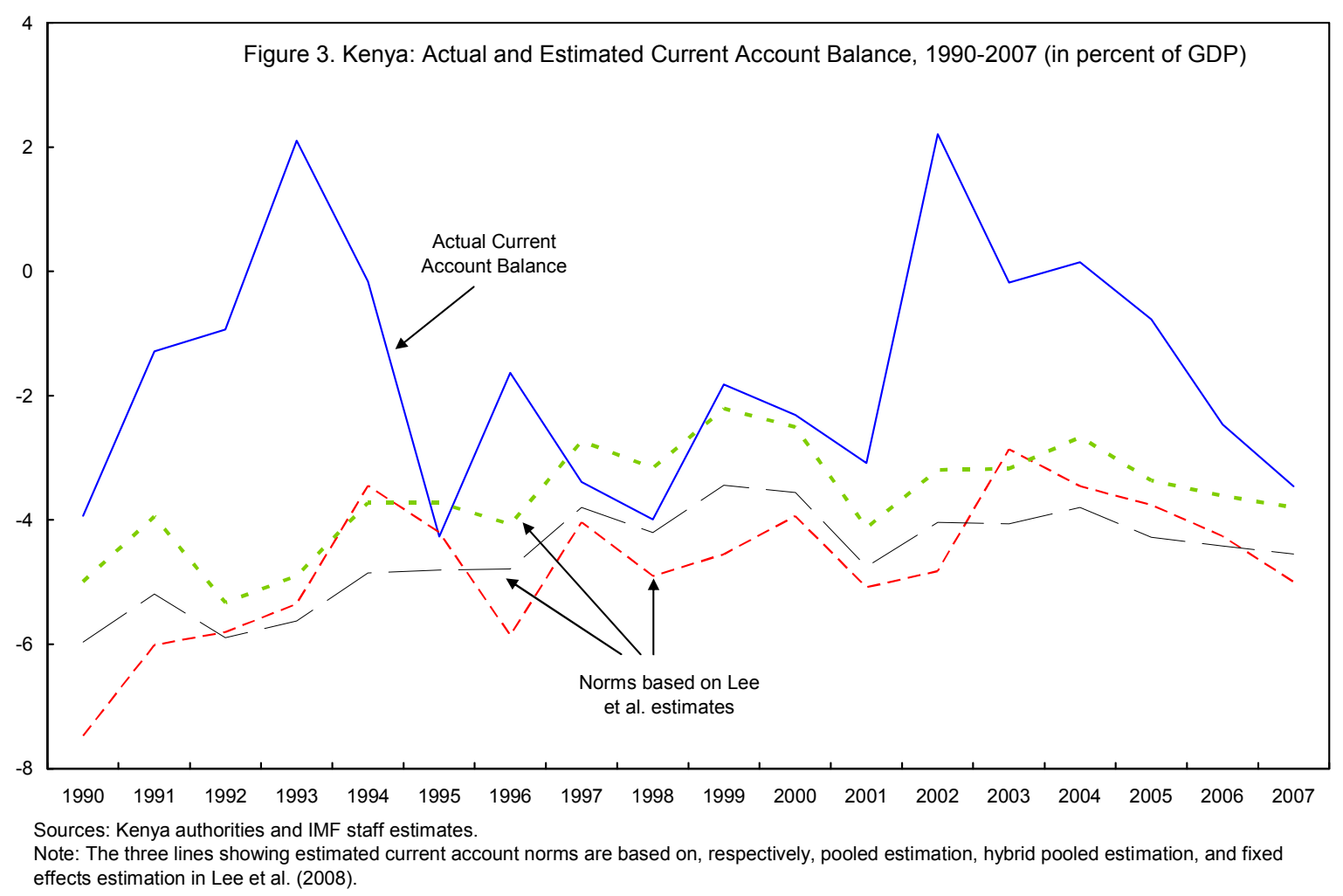

11. A third approach examines the relationship between the level of net foreign assetsas measured by the IIP - and Kenya's current account balance. The so-called external stability approach described in Lee et al. (2008) links a country's net foreign asset position to its net financial flows and allows estimation of the corresponding levels of the current account balance that will stabilize certain levels of net foreign assets for a given set of macroeconomic assumptions, particularly on GDP growth and inflation. A simplified version of the resulting formulas states:

$c a^{s}=\frac{g+\pi(1+g)}{(1+g)(1+\pi)} b^{s}$

where $c a^{\mathrm{s}}$ is the current account balance in percent of GDP, $g$ is the growth rate of GDP, $\pi$ is the inflation rate, and $b^{\mathrm{s}}$ is the net foreign asset position in percent of GDP stabilized by $c a^{\mathrm{s}}$. 
Table 3. Kenya: Illustrative scenarios of stabilizing the IIP

\begin{tabular}{lcccc}
\hline & \multicolumn{2}{c}{ Assumptions } & Net Foreign Assets & $\begin{array}{c}\text { Current Account } \\
\text { deficit (percent of } \\
\text { GDP) }\end{array}$ \\
\cline { 2 - 4 } & $\begin{array}{c}\text { GDP } \\
\text { Growth }\end{array}$ & Inflation & & $\mathbf{3 . 5}$ \\
\hline $\begin{array}{l}\text { NFA (2007) stabilizing } \\
\text { Current Account }\end{array}$ & 6.5 & 5.0 & -33.5 & 4.6 \\
$\begin{array}{l}\text { Current Account (2007) } \\
\text { stabilizing NFA }\end{array}$ & 6.5 & 5.0 & $\mathbf{- 4 3 . 5}$ & \\
\hline
\end{tabular}

Source: IMF staff estimates.

12. Assuming a medium-term GDP growth rate of 6.5 percent per year, and an inflation rate of 5 percent (Kenya's current target), the current level of Kenya's current account deficit (about 4.6 percent of GDP in 2007/08) would stabilize NFA at about -43.5 percent of GDP. To compare this level of NFA with Kenya's actual IIP position at the end of 2007, we made a rough estimation of the latter using annual balance of payments data. ${ }^{6}$ Our results suggest that Kenya's IIP at the end of 2007 was around -33.5 percent of GDP. Thus, should Kenya continue to run a current account deficit at its current level, its NFA would decline over time and eventually stabilizes at -43.5 percent of GDP. If Kenya wants to keep its NFA at the current level in the future, it would have to reduce the current account deficit to about 3.5 percent of GDP.

13. Two caveats are in order. First, the estimated current account norms and IIP for 2007 are both very preliminary and any conclusions drawn from them would need to be interpreted with great caution. Second, the sustainability of Kenya's foreign debt situation should be considered also in the context of its total public debt. Although Kenya's public foreign debt has declined in recent years, international experience suggests that Kenya should aim for some further reduction in the total public debt relative to GDP (see Chapter II). More broadly, the macroeconomic balance and external stability approaches applied here should be complemented by other approaches, including debt sustainability analysis.

\section{Competitiveness Assessment}

14. One indicator of a country's external competitiveness is unit labor cost, which is obtained by dividing labor cost by output (value added) per worker. An improvement in labor productivity without a fully offsetting increase in labor cost would, other things being equal, improve a country's cost-competitiveness. Figure 4 suggests that Kenya made impressive

\footnotetext{
${ }^{6}$ Kenya does not yet compile statistics on IIP. The estimation involves cumulating flows (including reserves) in the capital and the financial accounts of the balance of payments over time.
} 
strides in reducing unit labor cost during 2002-06, especially when compared with its two major East African Community (EAC) neighbors. However, it still lags behind China, which experienced a drastic decline in unit labor cost during 2002-05.

Figure 4. Change in Unit Labor Cost 1/ (percent)

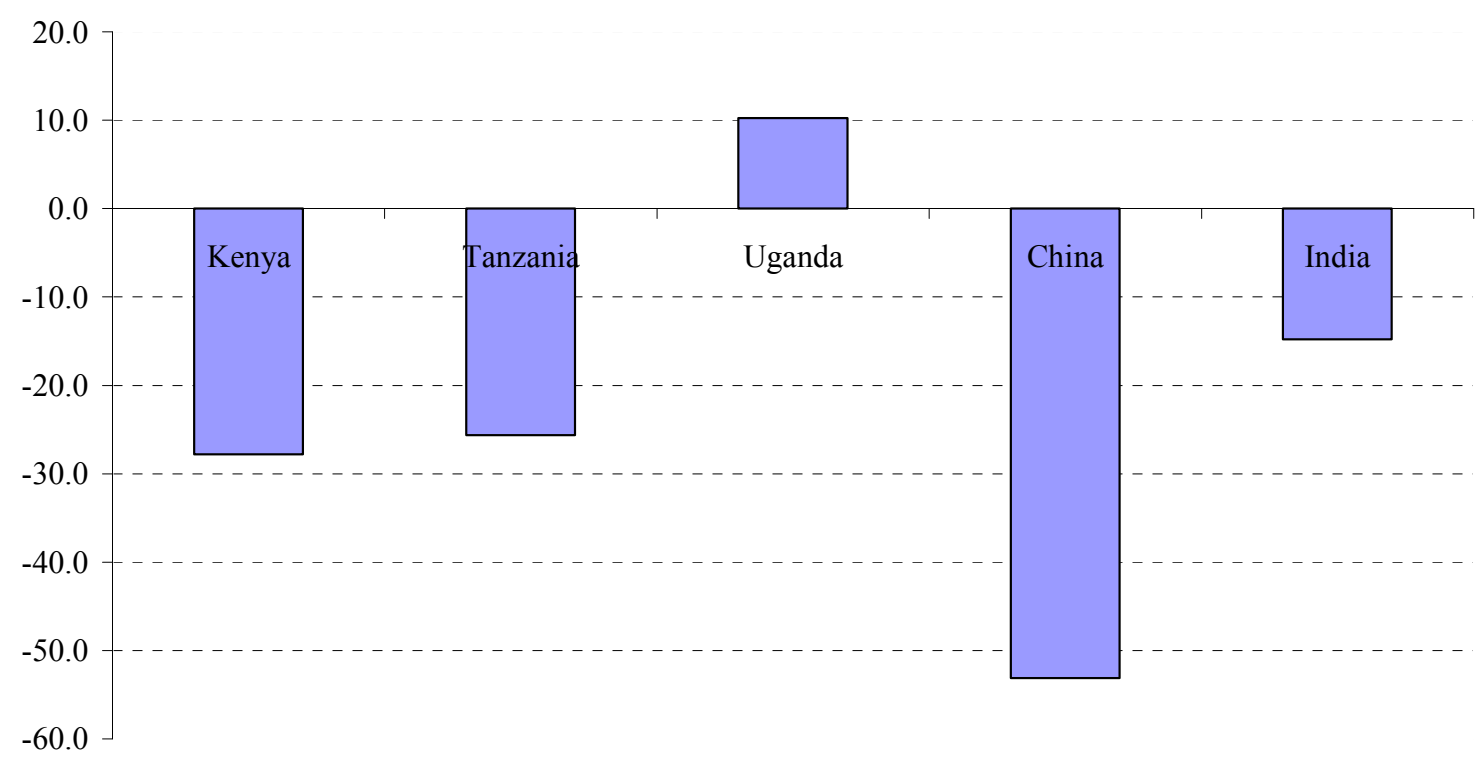

Source: IMF calcualtion based on World Bank Investment Climate Surverys.

1/ Changes are from 2002 to 2006 for Kenya and Tanzania, and 2002 to 2005 for all other countries.

15. The question is whether Kenya's reduced unit labor cost has translated into improved export competitiveness. This question can in part be answered by a constant market share analysis. $^{7}$ However, lack of up-to-date and consistent data makes this a difficult task. For example, Kenya's exports appear to be under-reported in the United Nations COMTRADE database when compared to data from the IMF's Direction of Trade Statistics (DOTS) and official balance of payments statistics. Under-reporting in the 2002 COMTRADE figures would be consistent with the finding of a World Bank study (Ng and Yeats, 2005), and appears to be confirmed by import data from Kenya's trading partners. For this analysis, we used data from the DOTS for values of total exports and adjusted Kenya's individual exports

\footnotetext{
${ }^{7}$ For an exposition of the constant market share analysis, see Leamer and Stern (1970). For applications of this approach in the context of IMF surveillance work, see Cady and Liu (2003) and Yang (2003). The analysis decomposes changes in exports over a period into four components: (i) global demand as indicated by global export growth; (ii) effects of export composition, i.e., whether the country happens to export commodities that are growing faster than the average of all commodities; (iii) effects of market distribution, i.e., whether the country's exports are concentrated in markets that are expanding faster than the global average; and (iv) a residual that indicates the supply side effect, often considered to reflect changes in competitiveness.
} 
(by commodity and by destination, based on COMTRADE data) across the board by an equal proportion so that they sum to the total DOT export values, both for 2002 and 2006.

16. Kenya's exports expanded slightly faster than world exports during 2002-06 (Table 4). This has stabilized Kenya's share of world exports after a long-term decline since 1977, when Kenya accounted for about 0.12 percent of total world exports (Figure 5). During 2002-06, however, there was no improvement in competitiveness; most of the expansion above the world pace was attributable to Kenya's increasing reliance on the SSA and the "rest of the world" markets, whose imports grew more rapidly than the world average (Table 5). ${ }^{8}$ Interestingly, the share of Kenyan exports destined for the fast-growing Asian market declined during the period.

Table 4. Decomposition of Cumulative Changes in Kenyan Exports, 2002-06

\begin{tabular}{lrr}
\hline Contribution from: & In Millions of US dollars & In Percent of Total \\
\hline Global expansion & 1,790 & 91 \\
Export composition & -143 & -7 \\
Market distribution & 330 & 17 \\
Competitiveness & -12 & -1 \\
Total & 1964 & 100 \\
\hline
\end{tabular}

Source: IMF staff estimates based on IMF DOT and UN COMTRAD data.

\footnotetext{
${ }^{8}$ Using the same approach, it was found in the 2006 Staff Report on Article IV Consultation that Kenya's export competitiveness improved during 2002-2005. This finding was influenced by the preliminary nature of the 2005 data on Kenya's exports, which were subsequently revised downward in the UN COMTRADE database.
} 
Figure 5. Kenya: Exports as Percent of World Exports (1950-2007)

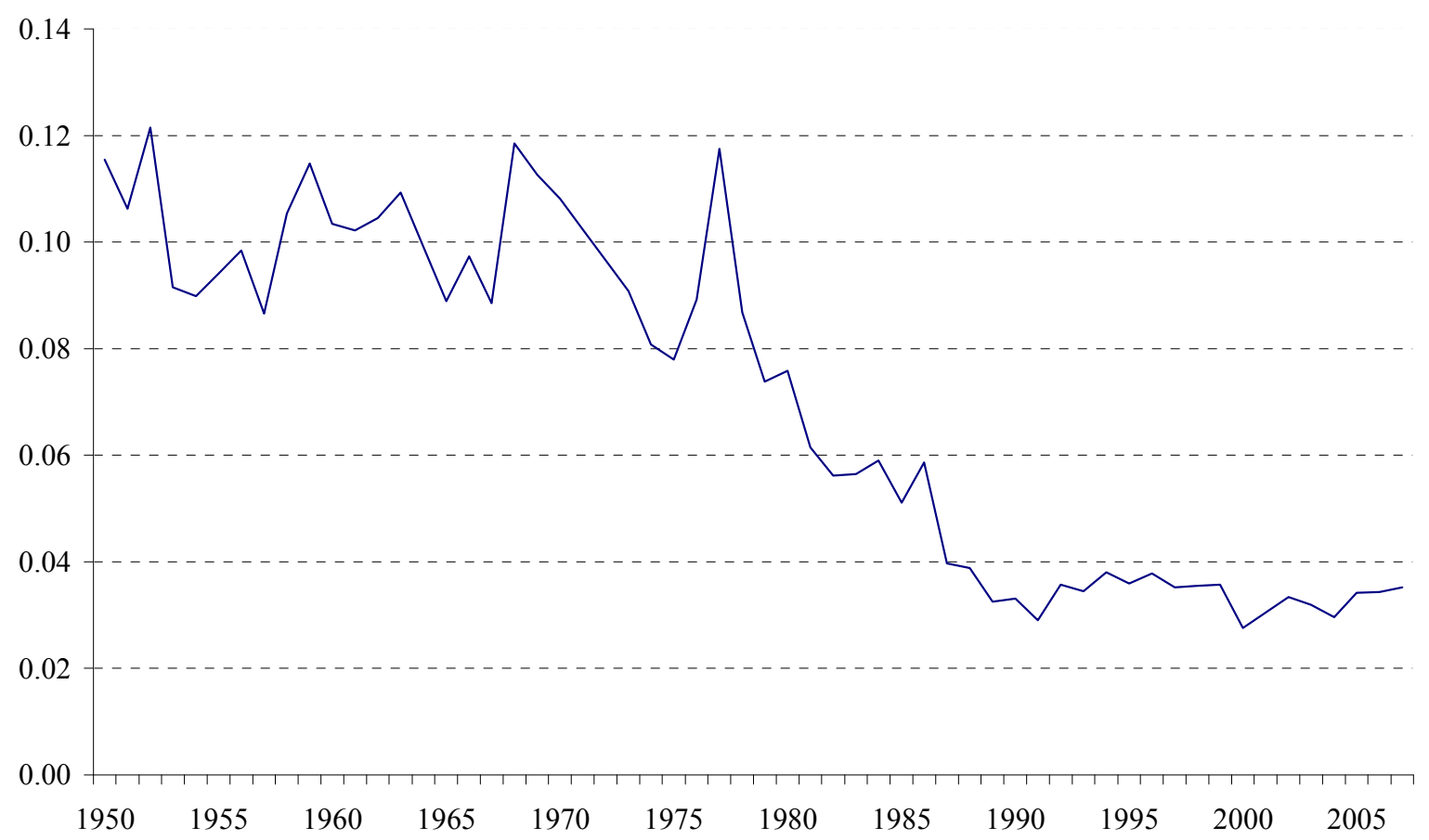

Table 5. Effects of Market Distribution on Kenyan Exports, 2002-06

\begin{tabular}{lccc}
\hline & \multicolumn{2}{c}{ Kenyan exports (percent of total) } & $\begin{array}{c}\text { Annual import growth } \\
\text { (percent) }\end{array}$ \\
\cline { 2 - 3 } & 2002 & 2006 & 19.4 \\
Asia & 13 & 10 & 16.0 \\
EU 25 & 37 & 26 & 11.7 \\
NAFTA & 10 & 8 & 20.6 \\
SSA & 29 & 39 & 19.3 \\
Rest of the world & 10 & 16 & 16.4 \\
World & 100 & 100 & \\
\hline
\end{tabular}

Source: IMF staff estimates based on IMF DOT and UN COMTRAD data.

17. Despite the booming global commodity markets, Kenya's export composition in general remained unfavorable for growth during the period. Among Kenya's top five exports at the two-digit level of the Standard International Trade Classification (SITC, Revision 1), which accounted for about 50 percent of Kenya total exports in 2006, only one (petroleum and petroleum products) had a world growth rate that was higher than the average for all exports during 2002-06 (Table 6). Similarly, only three of Kenya's top 10 exports faced world markets that were growing faster than the average. There are, however, some encouraging signs about Kenyan exports. Several of the top 10 exports, mostly manufactured goods, such as fishery and fish preparations, chemical elements and compounds, and nonmetallic mineral manufactures, were growing strongly - and the latter two products did so despite relatively slow world market expansion. 
Table 6. Annual growth of Kenya's ten top exports, 2002-06 (percent per year)

\begin{tabular}{lrrr}
\hline & 2006 value & Kenya growth & World growth \\
\hline SITC item & (US\$ million) & (percent) & (percent) \\
\hline Coffee, tea, cocoa, spices & 957 & 12.8 & 13.9 \\
Fruit and vegetables & 448 & 14.8 & 10.3 \\
Crude animal and vegetable material & 381 & 9.7 & 13.1 \\
Petroleum and petroleum products & 291 & 4.1 & 28.7 \\
Clothing & 275 & 17.9 & 9.7 \\
Fish and fish preparations & 151 & 40.0 & 25.9 \\
Chemical elements and compounds & 150 & 22.4 & 13.0 \\
Non-metallic mineral manufactures & 131 & 20.3 & 5.4 \\
Iron and steel & 104 & 27.4 & 12.3 \\
Machinery, other than electric & 96 & 23.3 & 17.7 \\
All exports & 4108 & 17.7 & 16.4 \\
\hline
\end{tabular}

Source: UN COMTRADE and IMF Direction of Trade.

18. The finding that Kenya's external competitiveness has not improved seems to contradict the prediction of falling unit labor cost. However, as Eifert et al. (2005) have shown, Kenya's labor productivity at factory floors has been relatively high among lowincome countries; what seems to be hampering improvements in Kenya's competitiveness are nonfactor costs. The World Bank's latest investment climate surveys (2008) suggest that costs related to infrastructure (roads, energy, and telecommunications), taxation, security, and bribes in Kenya are considerably higher than those in most of its competitors.

\section{Concluding Remarks}

19. The real appreciation of the shilling over the past three years through end 2007 is found to be driven largely by strong tea and coffee prices, a strengthening net foreign asset position, and improving productivity. Consistent with this finding, Kenya's external current account deficit also seems to have been at a sustainable level, but room for further widening without compromising external sustainability has shrunk over the past few years as the current account deficit continues to increase. Indeed, future developments need to be closely monitored given the projected further widening of the current account deficit over the medium term. Kenya's current account deficit in 2007 is near the level required to stabilize its 2007 NFA position although a somewhat lower level of NFA (i.e., larger negative value as a percent of GDP) may be sustainable. It is worth emphasizing, however, that these findings are preliminary and should be interpreted with caution given some of the data weaknesses. External sustainability should also be analyzed in conjunction with the assessment of public debt sustainability.

20. The shilling's recent appreciation does not appear to have undermined Kenya's export competitiveness so far. However, the recent productivity gains, which have been reflected in falling unit labor cost, do not appear to have translated into improved competitiveness in terms of an expanding market share, although it has contributed to the recent real appreciation of the shilling and may have helped to arrest the secular decline of 
Kenya's weight in the world export market. Strong import demand in Africa has helped Kenyan exports to expand, but this increasing reliance on regional markets makes Kenya vulnerable to an economic slowdown in the region. Diversification into emerging markets would help build a globally competitive export sector as well as reduce this vulnerability. While there are some encouraging signs that some of Kenya's key manufactured exports are growing strongly, its overall export composition remains unfavorable. Further improvements in Kenya's export competitiveness would require reducing nonfactor costs as well as continuing to raise factor productivity. 


\section{Data Appendix for Real Effective Exchange Rate Estimation}

Quarterly time series data were used from 1980Q1 -2007Q4. Where quarterly data were not available, linear interpolation was used to convert annual data to quarterly data.

Real Effective Exchange Rate (REER) - The actual REER comes from the IMF Institute through 1997. Beginning in 1997, a modified REER is calculated using IMF staff estimates of the CPI due to an overstatement of the official Kenyan CPI. The modified REER is scaled to the previous series for continuity around the 1997 period.

Productivity Differential - Real GDP per capita levels (using constant 2000 US Dollars), from the World Bank's World Development Indicators (WDI), are used as a proxy. The differential is calculated as the average index of GDP per capita levels for Colombia, Sri Lanka, Tanzania and Uganda over the index of GDP per capita level for Kenya.

Tea and Coffee Prices - An average of coffee and tea price indexes from the IMF's International Financial Statistics (IFS) is taken and deflated by the price of world merchandise exports.

Trade Openness - The sum of exports and imports of goods and services as a percent of GDP is taken from the IMF's World Economic Outlook (WEO) database.

Net Foreign Assets (NFA) - Banking sector NFA data as a percent of GDP are taken from IFS.

Other variables were considered but were not used because they either were not statistically significant or did not improve the fit of the model:

International Investment Position (IIP) - Because Kenya's IIP data are not available, a crude estimate of the IIP was constructed by using current account data from the IMF's WEO database.

Terms of Trade - Terms of trade data are taken from the IMF's WEO database.

Crude Oil Price - The crude oil price index is taken from the IMF's WEO database.

Public Expenditure - Public expenditure is measured as central government expenditure and net lending as a percent of GDP and is taken from the IMF's WEO database. 


\section{References}

Cady, J. and J. Liu, 2003. "External Competitiveness" in "Madagascar: Selected Issues and Statistical Appendix", IMF Country Report, No. 03/7, International Monetary Fund, Washington, January.

Cheng, K. C., 2004. "Estimation of the Equilibrium Real Exchange Rate for Kenya", in Kenya-Selected Issues and Statistical Appendix, International Monetary Fund, Washington.

Eifert, B. A. Gelb, and V. Ramachandran, 2005. "Business Environment and Comparative Advantage in Africa: Evidence from the Investment Climate Data", World Bank, Washington, August.

Kiptui, M. and L. Kipyegon, 2008. "External Shocks and Real Exchange Rate Movements in Kenya", paper prepared for presentation at the $13^{\text {th }}$ Annual Conference on Econometric Modeling in Africa, University of Pretoria, 9-11 July 2008.

Leamer, E. and R. Stern, 1970. Quantitative International Economics, Allyn and Bacon, Boston.

Lee, J., G.M. Milesi-Ferreti, J. Ostry, A. Prati, and L.A. Ricci, 2008. "Exchange Rate Assessments: CGER Methodologies”, Occasional Paper, No. 261, International Monetary Fund, Washington.

Ng, F. and A. Yeats, 2005. "Kenya: Export Prospects and Problems", Africa Region Working Paper Series No. 90, World Bank, Washington.

Stock, James H., and Mark W. Watson, 1993. "A Simple Estimator of Cointegrating Vectors in Higher Order Integrated Systems," Econometrica, Vol. 61, Issue 4 (July), pp.783820 .

World Bank, 2008. “Kenya: Accelerating and Sustaining Growth”, Report No. 42844-KE, World Bank, Washington.

Yang, Y., 2003. "Trade Strategy for Sustained Growth", in "The Republic of Kazakhstan: Selected Issues and Statistical Appendix", IMF Country Report 03/211, International Monetary Fund, Washington, July. 


\section{Public Debt Thresholds for Kenya ${ }^{1}$}

\section{A. Introduction}

1. Anchoring medium-term fiscal policy on a gradual reduction of the net domestic debt-to-GDP ratio has served Kenya well in the past. Risk premia have fallen, the reduction of interest payments in the budget has provided fiscal space for higher primary expenditures, and the strategy to gradually reduce domestic debt-to-GDP has provided room for absorbing unforeseen contingent liabilities. Also, the focus on limiting net domestic financing has, absent major other sources of financing - e.g. privatization receipts, budgetary donor support, nonconcessional external financing - implied that sharp fiscal expansions have been avoided in the recent past.

2. However, Kenya's emerging access to international financial markets and volatile privatization receipts argue for shifting away from a primary focus on net domestic financing (NDF). The current fiscal framework is not well adapted to take into account other sources of nonconcessional debt, such as the US\$ 500 million Eurobond included in the 2008/09 budget, which could ease the NDF needs, but not the overall public debt burden. Also, the volatility of large but lumpy privatization receipts could lead to large variations in spending from one year to the next, for a given level of NDF. ${ }^{2}$ More generally, with sources of financing other than NDF increasing, the budget could imply an unduly large fiscal impulse, while still being consistent with NDF targets.

3. The analysis in this chapter suggests that a broader measure such as overall public debt may be a better future anchor for medium-term fiscal policy. It would take into account both domestic and external public debt. ${ }^{3}$ Ideally, anchoring fiscal policy on the government's net worth could better take into account government asset changes, including from privatizations, but data limitations in Kenya make such an approach difficult to implement.

4. The chapter argues that Kenya should seek to limit its overall public debt-to-GDP level to around 35 percent when anchoring medium-term fiscal policy. By estimating a 'threshold' or upper bound for public debt (as a percent of GDP), this paper seeks to answer whether the public debt-to-GDP ratio should be allowed to increase, remain stable, or instead decrease from its current level, which is estimated at 38.8 percent of GDP for end-June 2008. Using evidence from a cross-country panel and other historical information, the paper

\footnotetext{
${ }^{1}$ Prepared by G. Everaert (FAD). The author wishes to thank Gabriel Di Bella for sharing data on Institutional Investor ratings, and Tom Krueger, Yongzheng Yang, Jan Gottschalk, Kadima Kalonji, and participants at the June 28 seminar in Nairobi for valuable comments.

${ }^{2}$ Unless spending from privatization receipts is spread over time.

${ }^{3}$ Central government domestic debt and public and publicly guaranteed external debt.
} 
concludes that Kenya's medium-term fiscal policy should aim to limit public debt at around 35 percent of GDP.

\section{B. Deriving a Debt Threshold}

5. Three approaches are used in this paper to derive a debt threshold for Kenya. First, we simulate at which level of debt Kenya becomes less 'debt intolerant', in line with Reinhart, Rogoff and Savastano (2003). Second, we use historical primary surpluses to derive a sustainable level of debt. Finally, we look at historical primary surpluses under a less favorable setting. The traditional Fund-Bank debt sustainability analysis is a fourth approach to assess the sustainability of current fiscal policies, and is discussed in a Supplement to the staff report. ${ }^{4}$

\section{Debt Intolerance approach}

6. Reinhart, Rogoff, and Savastano (2003) introduced the concept of degrees of 'debt intolerance. ${ }^{5}$ They observed that some countries enjoy uninterrupted access to capital markets, whereas other countries would only have intermittent or no access at all. They referred to this as the different degrees of 'debt intolerance' that markets exhibit. Moreover, they showed that the relation between debt intolerance and the level of debt is nonmonotonic, with some highly indebted countries having easier market access than some countries with lower levels of debt. Indeed, some countries experience debt crisis even at relatively low levels of debt that seem manageable for other countries.

7. Building on this concept, we estimate a threshold level of public debt for Kenya as the level of debt at which Kenya becomes less debt intolerant. Following Reinhart, Rogoff, and Savastano (2003) (RRS), and a recent adaptation by Di Bella (2008), the methodology we use in the first approach involves two steps.

- $\quad$ First, the relation between debt intolerance and public debt-to-GDP ratios is estimated to obtain estimation coefficients. Countries are first divided into 3 groups according to their level of debt intolerance, as summarized in their Institutional Investor rating (IIR) - a rating ranging from 0 to 100 published bi-yearly (March and September) in the Institutional Investor magazine that characterizes countries in terms of attractiveness as investment destinations. ${ }^{6}$ RRS show that the IIR is highly correlated with default spreads for those countries where market-based default spreads are available. The advantage of using the IIR, as opposed to a market-based spread, is that this rating is also available for countries, such as Kenya, that have not yet issued

\footnotetext{
${ }^{4}$ However, it does not include specific thresholds for assessing total public debt.

${ }^{5}$ Their work focused on external debt, as opposed to total public debt.

${ }^{6}$ A higher rating reflects a country’s higher attractiveness as an investment destination.
} 
external sovereign debt. Following Di Bella (2008), countries in club A have an IIR higher than one standard deviation above the mean and are considered relatively debt tolerant, whereas countries in club C are very debt intolerant with an IIR lower than one standard deviation below the mean. Countries in club B fall in between the two (Table 1).

Table 1. Country Clubs as a Function of the Degree of Debt Tolerance

$\begin{array}{lll}\text { market access is ... } & \text { debt tolerance is ... IIR rating }\end{array}$

\begin{tabular}{rccc} 
Club A & $\ldots$ continuous & $\ldots$ high & IIR $>$ mean +1 standard deviation \\
Club B & $\ldots$ intermittent & $\ldots$ indeterminate & mean +1 standard deviation $>$ IIR $>$ mean -1 standard deviation \\
$B 1$ & & & mean +1 standard deviation $>$ IIR $>$ mean \\
B2 & & mean $>$ IIR $>$ mean -1 standard deviation \\
Club C & $\ldots$ virtually absent & $\ldots$ low & IIR $<$ mean -1 standard deviation \\
\hline
\end{tabular}

Figure 1. Kenya: IIR rating (1979-2008)

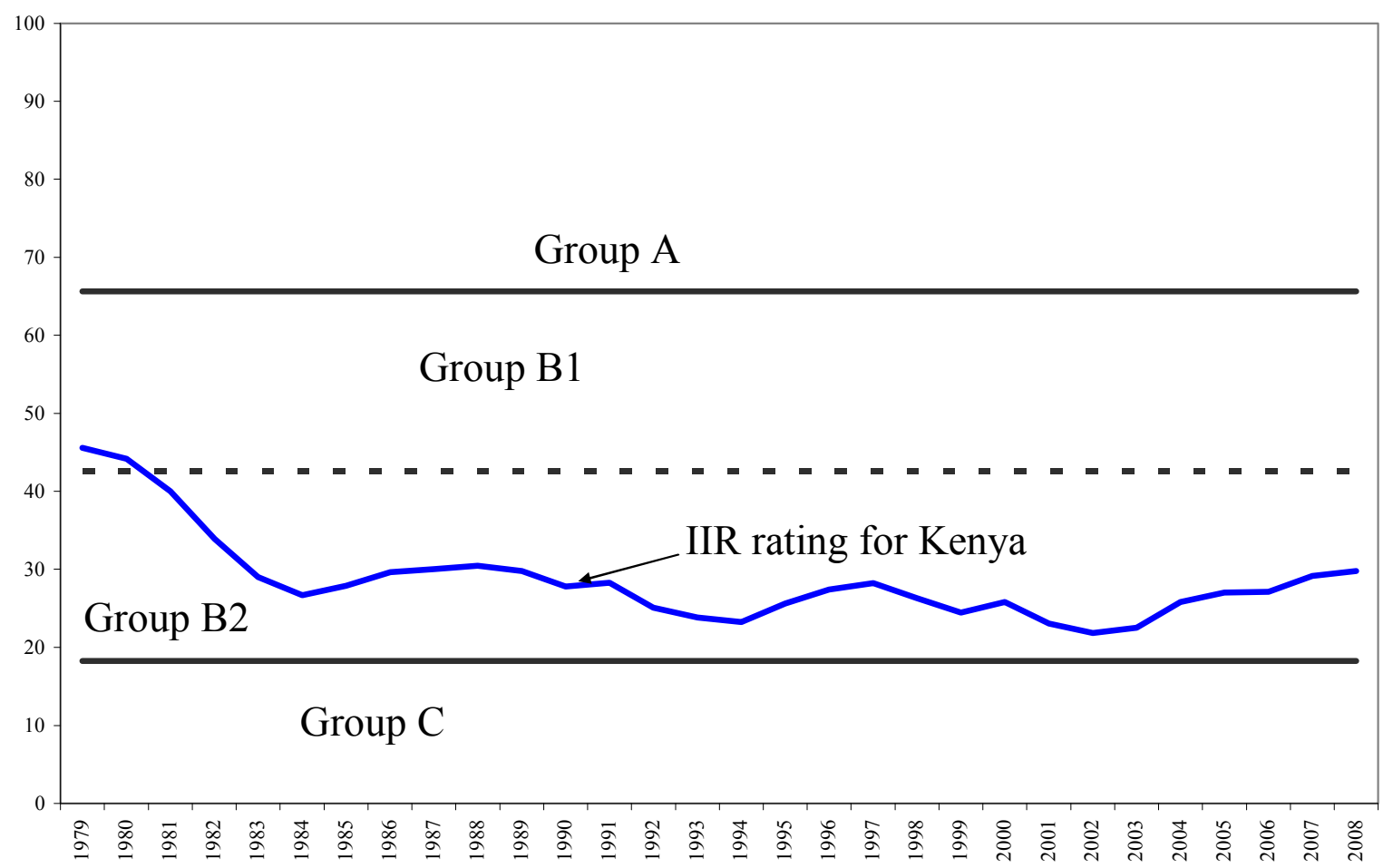

Then, the relation between the IIR rating and the level of public debt is estimated for a large set of countries, including Kenya, after controlling for the frequency of highinflation periods, in line with RRS who find this to be significant. As RRS argue that markets keep a 'long memory' of past default risk, and therefore, countries take a long time to permanently move into a less debt intolerant club, we use historical averages for most variables in the regressions, and hence, simple cross-section regressions techniques. The estimation formula is as follows: 
$I I R_{i}=a+b_{1} X_{1 i}+b_{2} X_{2 i}+b_{3} X_{3 i}+b_{4} X_{4 i}+b_{5} X_{5 i}+\varepsilon_{i}$

where IIR is the average Institutional Investor rating for the sample period, $\mathrm{X}_{1 \mathrm{i}}$ is the average public debt-to-GDP ratio times a dummy with value 1 for countries in club $\mathrm{A}, \mathrm{X}_{2 \mathrm{i}}$ is the average public debt-to-GDP ratio times a dummy with value 1 for countries in club $\mathrm{B}, \mathrm{X}_{3 \mathrm{i}}$ is the average public debt-to-GDP ratio times a dummy with value 1 for countries in club $\mathrm{C}, \mathrm{X}_{4 \mathrm{i}}$ is the average public debt-to-GDP ratio times a dummy with value 1 for countries not in club $\mathrm{A}, \mathrm{X}_{5 \mathrm{i}}$ is the percent of 12-month periods since 1979 where inflation exceeds 40 percent - a level that has been considered in the literature a reasonable threshold for high inflation - and $\varepsilon_{i}$ is the error term. Estimation results are summarized in Table 2, and clearly show that the relation is non-monotonic, as the coefficient on the public debt-to-GDP ratio for Club A countries is positive and statistically significant, whereas that for non-Club A countries is negative and statistically significant. Also, periods of high inflation are associated with lower creditworthiness, as expected. ${ }^{7}$

Table 2. Cross-Section Regression Results

\begin{tabular}{|c|c|c|c|c|c|c|c|c|c|c|c|}
\hline \multirow{2}{*}{$\begin{array}{l}\text { regression } \\
\text { number }\end{array}$} & \multicolumn{2}{|r|}{ constant } & \multicolumn{2}{|l|}{$\begin{array}{l}\text { X } 1 \\
\text { (club A) }\end{array}$} & $\begin{array}{l}\text { X2 } \\
\text { (club B) }\end{array}$ & $\begin{array}{l}\text { X3 } \\
(\text { club C) }\end{array}$ & $\begin{array}{l}\text { X4 } \\
\text { (not club A) }\end{array}$ & $\begin{array}{l}\text { X5 } \\
\text { (inflation) }\end{array}$ & $\begin{array}{l}\text { Adjusted R } \\
\text { square }\end{array}$ & Obs. & Sample period \\
\hline & 1 & $46.63 *$ & $0.52 *$ & & & & $-0.16 * *$ & $-0.16 *$ & 0.638 & 128 & $1979-2008 \mathrm{1} /$ \\
\hline & 2 & $45.19 *$ & $0.54 *$ & $* *$ & $-0.12 * *$ & $-0.21 * *$ & & -0.01 & 0.639 & 128 & $1979-20081 /$ \\
\hline & 4 & $53.73 *$ & $0.45 *$ & $* *$ & $-0.11 *$ & $-0.26 * *$ & & $-0.24 * *$ & 0.753 & 79 & $1979-20082 /$ \\
\hline & 5 & $50.71 *$ & $0.46 *$ & $* *$ & & & $-0.19 * *$ & $-0.18 *$ & 0.596 & 128 & 1994-2008 \\
\hline & 6 & $48.84 *$ & $0.49 *$ & $* *$ & $-0.14 * *$ & $-0.23 * *$ & & -0.14 & 0.609 & 128 & 1994-2008 \\
\hline
\end{tabular}

** denotes significance at the 5 percent level, * denotes significance at the 10 percent level.

Sources: Institutional Investor, RRS, IFS, and Fund staff estimates.

1/ Sample includes countries that had an IIR later than 1979.

2/ Sample restricted to countries with an IIR rating in 1979.

- $\quad$ Second, using the coefficients from the cross-section regression, we simulate at what level of debt Kenya would 'graduate' to a less debt intolerant club. As Kenya's average IIR indicates its membership in club B2, we estimate at which level of public debt Kenya would become a B1-country. Given the negative coefficient on public debt for group B countries, a lower level of public debt would achieve a higher IIR rating. We display the results in Table 3 using the coefficients from regressions two and six.

\footnotetext{
${ }^{7}$ To avoid potential endogeneity between the variable periods of high inflation and sovereign risk, regressions were also performed using the time spent under high inflation since 1958, such that the inflation variable is mostly pre-determined to the sample period used. Results are generally robust to using this variable.
} 
Table 3. Kenya: Predicted IIR, Public Debt, and Club Ranking

\begin{tabular}{|c|c|c|}
\hline \multirow[b]{2}{*}{ Public debt/GDP } & Regression 2 & Regression 6 \\
\hline & Predicted IIR Club & Predicted IIR Club \\
\hline 60 & 37.7 B2 & $40.0 \mathrm{~B} 2$ \\
\hline 55 & $38.4 \mathrm{~B} 2$ & $40.7 \mathrm{~B} 2$ \\
\hline 40 & $40.2 \mathrm{~B} 2$ & $42.8 \mathrm{~B} 2$ \\
\hline 35 & $40.8 \mathrm{~B} 2$ & $43.5 \mathrm{~B} 2$ \\
\hline 30 & $41.4 \mathrm{~B} 2$ & $44.1 \mathrm{~B} 1$ \\
\hline 25 & $42.1 \mathrm{~B} 1$ & $44.8 \mathrm{~B} 1$ \\
\hline 20 & $42.7 \mathrm{~B} 1$ & $45.5 \mathrm{~B} 1$ \\
\hline 25 & $42.1 \mathrm{~B} 1$ & $44.8 \mathrm{~B} 1$ \\
\hline 20 & $42.7 \mathrm{~B} 1$ & $45.5 \mathrm{~B} 1$ \\
\hline 15 & $43.3 \mathrm{~B} 1$ & $46.2 \mathrm{~B} 1$ \\
\hline 10 & $43.9 \mathrm{~B} 1$ & $46.9 \mathrm{~B} 1$ \\
\hline 5 & $44.5 \mathrm{~B} 1$ & $47.6 \mathrm{~B} 1$ \\
\hline 0 & $45.1 \mathrm{~B} 1$ & $48.3 \mathrm{~B} 1$ \\
\hline
\end{tabular}

Source: Fund staff calculations.

8. Kenya would enter a less debt intolerant club at a level of public debt at 30-35 percent of GDP, with some variation around this number depending on the specific regression and sample period used, and confidence intervals around these point estimates.

\section{Primary surpluses approach}

9. Future primary surpluses also give an indication of the sustainable level of debt. In line with IMF (2003), the present discounted value (PDV) of future primary surpluses can be used to assess a debt threshold (as a percent of GDP) using the following formula:

$P D V=\int_{0}^{\infty} p_{t} \exp -\{(r-g) t\} d t \approx \frac{p}{r-g}$

where $\mathrm{p}_{\mathrm{t}}$ denotes the primary surplus in period $\mathrm{t}, \mathrm{r}$ stands for the real interest rate, and $\mathrm{g}$ for the real growth rate. This approach builds on the idea that future primary surpluses need to be sufficiently high to pay back the present level of public debt. High real interest rates make the sustainable level of debt lower, but high real GDP growth rates facilitate a higher sustainable level of public debt (as a percent of GDP).

10. One approach is to derive the sustainable level of debt by assuming that future primary surpluses will be similar to historical averages. Assuming that past fiscal policy gives an indication of what can be achieved in the future, historical average primary surpluses are used to calculate the above public debt ratio. The discount rate used is the difference between the average real interest rate and real output growth. The real interest rate is proxied by the real LIBOR rate (for US\$ debt) plus a country-specific risk-spread derived 
from the relative spread between the IIR rating between Kenya and the U.S. Due to data limitations, we use a shorter sample period (1994/95-2007/08) for this exercise.

11. On these assumptions, Kenya could sustain a public debt around 31 percent of GDP (Table 4). These assumptions imply high primary surpluses, but modest growth, as witnessed in the past, where fiscal policy has reacted positively to rising public debt-to-GDP ratios, thereby ensuring fiscal sustainability (Figure 2 ). ${ }^{8}$ These assumptions therefore do not take into account that future policy may shift away from the past track record. Important to note is that $2007 / 08$ was the first year in which Kenya experienced a negative primary surplus.

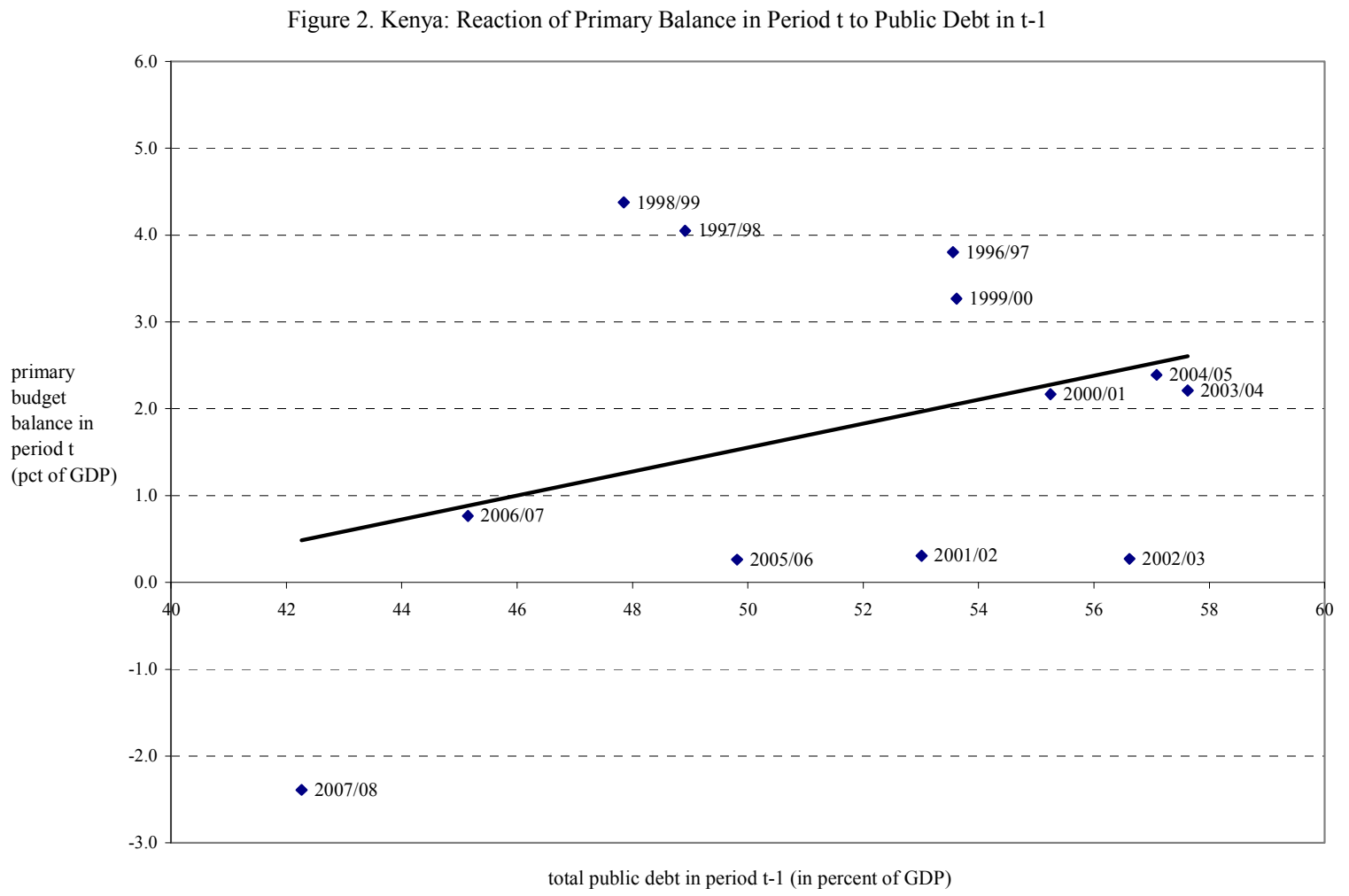

12. Alternatively, if future growth is believed to be permanently higher than in the past, such as under current growth projections of 6.5 percent real GDP growth over the medium term, a higher level of public debt would be sustainable. However, this still assumes historical averages for the primary balance. Once one takes into account the likelihood of lower future primary balances, such as the 2006/07 outturn, a much higher growth rate (of up

\footnotetext{
${ }^{8}$ Correlation coefficient is 0.34 percent.
} 
to 8.3 percent) would be needed to sustain the level of debt that was estimated on historical assumptions. $^{9}$

Table 4. Kenya: Primary Surpluses and Sustainable Level of Public Debt

\begin{tabular}{|c|c|c|c|}
\hline & \multirow[t]{2}{*}{ Historical baseline } & \multicolumn{2}{|c|}{ Other scenarios } \\
\hline & & 6.5 pct growth & $\begin{array}{l}06 / 07 \text { primary balance } \\
\text { and } 8.3 \text { pct growth }\end{array}$ \\
\hline & \multicolumn{3}{|c|}{ (In percent of GDP, unless otherwise indicated) } \\
\hline Average primary balance $1 /$ & 2.3 & 2.3 & 0.8 \\
\hline \multicolumn{4}{|l|}{ Average real interest rate (in percent) } \\
\hline Average real LIBOR rate (in percent) & 1.8 & 1.8 & 1.8 \\
\hline Average risk premium (in percent) & 9.0 & 9.0 & 9.0 \\
\hline Average real growth rate (in percent) & 3.4 & 6.5 & 8.3 \\
\hline Benchmark level of debt & 31.1 & 53.7 & 31.1 \\
\hline \multicolumn{4}{|l|}{ Memorandum Item: } \\
\hline Total public debt in $2007 / 08$ & 38.8 & & \\
\hline
\end{tabular}

Source: Institutional Investor, IFS, and Fund staff calculations.

1/ Cash basis.

\section{Primary surpluses with shocks approach}

13. As a variation on the previous approach, a revenue shock that cannot be fully offset through expenditure reductions would imply lower primary balances, and hence sustainable levels of public debt. On the revenue side, this shock is assumed to be permanent and one and a half standard deviations below the historical average. On the expenditure side, as fiscal policy can adjust to shocks, expenditures are adjusted downward using the historical average downward expenditure adjustment. The resulting primary balance, and derived sustainable debt are calculated as under the previous approach and are summarized in Table 5.

\footnotetext{
${ }^{9}$ In principle, an infinite number of scenarios are possible. However, a reasonable set of assumptions was chosen to derive a relevant public debt threshold, or to illustrate sensitivity to assumptions used.
} 
Table 5. Kenya: Sustainable Public Debt With Incomplete Shock Absorption

\begin{tabular}{|c|c|c|c|c|}
\hline & \multirow{2}{*}{\multicolumn{2}{|c|}{$\begin{array}{l}\text { Historical baseline Historical baseline } \\
\text { (as in Table 4) after shock }\end{array}$}} & \multicolumn{2}{|c|}{ Alternative scenarios } \\
\hline & & & 6.5 percent growth & $\begin{array}{l}2006 / 07 \text { rev. \& exp. } \\
\& 10.7 \text { pet growth }\end{array}$ \\
\hline & \multicolumn{4}{|c|}{ (In percent of GDP, unless otherwise indicated) } \\
\hline Revenues (including grants) & 22.0 & 20.3 & 20.3 & 20.9 \\
\hline Average & 22.0 & 22.0 & 22.0 & 22.6 \\
\hline Standard deviation & $\ldots$ & 1.2 & 1.2 & 1.2 \\
\hline Primary Expenditure & 19.7 & 18.9 & 18.9 & 20.9 \\
\hline Average $1 /$ & 19.7 & 19.7 & 19.7 & 21.8 \\
\hline Average downward adjustment & $\ldots$ & -0.9 & -0.9 & -0.9 \\
\hline Average primary balance $2 /$ & 2.3 & 1.4 & 1.4 & 0.0 \\
\hline Average real interest rate (in percent) & 10.7 & 10.7 & 10.7 & 10.7 \\
\hline Average real LIBOR rate (in percent) & 1.8 & 1.8 & 1.8 & 1.8 \\
\hline Average risk premium (in percent) & 9.0 & 9.0 & 9.0 & 9.0 \\
\hline Average real growth rate (in percent) & 3.4 & 3.4 & 6.5 & 10.7 \\
\hline Benchmark level of debt & 31.1 & 19.3 & 33.7 & 31.1 \\
\hline \multicolumn{5}{|l|}{ Memorandum Item: } \\
\hline Total public debt in 2007/08 & 38.8 & & & \\
\hline
\end{tabular}

Source: Institutional Investor, IFS, and Fund staff calculations.

1 / Including adjustment for cash.

2/ Cash basis.

14. After a shock, the sustainable level of public debt would decline from 31.1 percent of GDP to 19.3 percent of GDP. The partial expenditure adjustment after a revenue shock results in a lower primary surplus, and hence, a lower estimated sustainable level of public debt (as a percent f GDP). As in Table 4, an alternative scenario with higher real GDP growth at 6.5 percent is considered, and raises the estimated sustainable level of public debt to about 34 percent of GDP. However, recent trends in revenues expenditures have resulted in lower than historical primary surpluses. Therefore, using 2006/07 outturn data for revenue and expenditures and assuming a revenue shock to the 2006/07 baseline would require a level of real GDP growth as high as 10.7 percent to sustain a level of public debt similar to the baseline of Table 4 of 31.1 percent of GDP.

\section{Summary findings}

15. The three approaches used above broadly converge that 35 percent of GDP is an acceptable level for public debt-to-GDP in Kenya. While estimates differ somewhat depending on the methodology and sample period used, overall, the results indicate that a level of public debt at about 35 percent of GDP seems broadly appropriate.

16. Hence, Kenya's medium-term expenditure framework could be guided by anchoring public debt (as a percent of GDP) to decline to about 35 percent of GDP. While this would 
require some adjustment on current policies, and such policies would need to be identified in future budgets, this is consistent with the authorities' plans in the Budget Strategy Paper.

\section{Other Evidence}

17. The result that Kenya should target public debt at around 35 percent of GDP is broadly consistent with the literature. Using a large sample of emerging market economies, an IMF (2003) study concludes that for the typical emerging market economy, the sustainable level of public debt is often quite low: (i) a sustainable level of public debt based on past fiscal performance may only be 25 percent of GDP on average; and (ii) countries typically fail to adjust fiscal policy in a manner consistent with ensuring fiscal sustainability once public debt exceeds 50 percent of GDP. ${ }^{10}$ Other studies have looked at external debt separately, and estimated thresholds of 40 percent for the net present value of external debtto-GDP (IMF, 2002), which is also the threshold used in the traditional Fund-Bank debt sustainability analysis for 'medium' performing countries such as Kenya. ${ }^{11}$ RRS (2003) also report that 70 percent of emerging market economies that never defaulted kept external debt below 45 percent of GDP, and that over half of middle income countries without a history of default had ratios of external debt-to-GDP below 35 percent. Therefore, RRS argue that external debt of 35 percent of GDP would be a minimum safety threshold for countries that did not make it yet into club A.

\section{Concluding remarks}

18. While numerical thresholds are useful guide posts, they have also limitations. First, data on public debt currently still exclude contingent liabilities, for which the government could be ultimately liable. Second, both government solvency and liquidity issues are important. For instance, the lumpiness of repayments on external debt acted as a constraint on fiscal policy in the past, especially when this coincided with difficult economic conditions such as droughts, or other shocks. ${ }^{12}$ The maturity profile of public debt and rollover risk have to be taken into account as well, and in the past, the large share of domestic debt at short maturity significantly increased rollover risk.

19. A comprehensive overall debt and debt management strategy is a useful complement to the medium-term targeting of a public debt-to-GDP ratio. The authorities' debt

\footnotetext{
${ }^{10}$ This is much in contrast with developed countries, whose primary surpluses react progressively stronger to rising debt up to public debt levels of 80 percent of GDP, and where the sustainable level of debt is estimated to average 75 percent of GDP (IMF, 2003).

${ }^{11}$ Countries are classified as 'weak', 'medium', and 'strong' according to certain country-specific and institutional characteristics, summarized in the CPIA rating.

${ }^{12}$ E.g. In 2000/01 when Kenya was hit by a severe drought, external debt service peaked to 3.6 percent of GDP. Eventually, a Paris Club rescheduling was agreed following the approval of a new IMF arrangement.
} 
management strategy could usefully take into account not only the size of the public debt, but also issues of maturity, debt composition, concessionality, repayment profile, and liquidity risk.

\section{E. References}

Reinhart, Carmen, Kenneth S. Rogoff, and Miguel A. Savastano, 2003, Debt Intolerance, Brookings Papers in Economic Activity.

International Monetary Fund, 2002, Assessing Sustainability, Washington D.C., available via the internet: www.imf.org/external/np/pdr/sus/2002/eng/052802.htm.

International Monetary Fund, 2003, Public Debt and Fiscal Policy in Emerging Market Economies in World Economic Outlook, Fall, September 2003.

International Monetary Fund, 2005, Fiscal Responsibility Laws, Washington D.C. (unpublished).

Di Bella, Gabriel, 2008, A Stochastic Framework for Public Debt Sustainability Analysis, International Monetary Fund Working Paper 08/58. 